\title{
The Development of Mathematics Learning tool to Improve Critical Thinking Ability and Self Efficacy By using Problem Based Learning of State Senior High School Sultan Iskandar Muda Medan
}

\author{
Wilda Lubis \\ Student of magister Education Degree, \\ State University of Medan \\ Medan, Indonesia \\ Wildalubis37@gmail.com
}

\author{
Yulita Molliq \\ Lecture at Faculty of Mathematics and Sciences \\ State University of Medan \\ Medan, Indonesia \\ Kms.M. Amin Fauzi \\ Lecture at Faculty of Mathematics and Sciences \\ State University of Medan \\ Medan, Indonesia
}

\begin{abstract}
The research aims to determine: (1) the effectiveness of learning instruments are developed, (2) the increasing the ability to critical thingking and self efficacy of student using learning instruments developed. This research is development research. Development model used is Dick and Carrey model which consists of ten stages. The results of the defining phase is used to design a learning instruments, then this draft is validated and tested in classroom to see its effectiveness. The populations of this research are all of the students at Senior High School and the sample choosen is purposive subject Which are in eleven grade 1 of Sultan Iskandar Muda Senior High School. From the results of trials I and field trials II obtained : 1) learning devices that meet the criteria of effectiveness, effectiveness in terms of a) students learning completeness in the classically, b) achievement of learning purpose; and c) learning time; 2) improvement creative thinking and problem solving mathematically ability of students by using learning devices based inquiry model; Futhermore, it is suggested that teachers can use the inquiry model as an alternative model of learning, with guidance or questions can be affordable given by students, so that students more easily understand the problems given.
\end{abstract}

Keywords: learning materials, problem based learning, Dick and Carrey model, the ability of critical thingking and self efficacy.

\section{INTRODUCTION}

Education is an important part of this life. The progress of a nation can be seen from the quality of education in the country. Education is a means to realize human resources that have reliable knowledge, skills and attitudes and can help solve all the problems that exist in this nation. According to NCTM 2000[1] the purpose of learning mathematics is to develop: the ability to explore, construct conjectures, and formulate reason logically, the ability to solve non-routine problems, the ability to communicate mathematically and use mathematics as a communication tool, the ability to connect between mathematical ideas as a communication tool. In order to make mathematics learning easier teaching mathematics that is teacher centered and the use of formulas alone must be abandoned so that the mathematical abilities of students develop well. In line with the opinion of Simbolon; Mulyono; Sun; Syahputra (2017)[2] revealed that "critical thinking skills are needed in learning mathematics, because it has a very dominant role in educating students. Students are expected to be able to manage information in order to survive in a state that is always changing, uncertain and competitive ".

Field experience shows that activities to develop critical thinking skills are not in line with expectations. This fact was found in the initial observations at high school in Sultan Iskandar Muda that from the test questions given to 38 students $60 \%$ of them did not understand the problem correctly, $40 \%$ of students were unable to find the concept to solve the problem correctly, $15 \%$ of students could not show supporting evidence for correct generalization. In addition to the low critical thinking skills of students, low self-efficacy also influences students' knowledge and understanding of mathematics. So that to improve the ability to think citis and self efficacy students need learning tools that support this. 


\section{METHOD}

This type of research is development research. The type of development research used was Dick and Carey. The subjects of this study were all students of the eleventh grade of senior high school Sultan Iskandar Muda Medan, while the object of this study was a mathematics learning tool with linear program material. The research design division consists of 5 stages, namely a limited trial design, field trial design, development of learning tools, development of research instruments and an analysis of improving students' critical thinking skills.

\section{A. The trial design is legibility}

Readability testing (limited) intends to find out the practicality of the device being developed, so data collection is done about the feasibility of the learning device and the response of the teacher and students regarding the learning device. Observation of the feasibility of the learning device is an observation phase using the device implementation sheet. At the end of the teacher's activity and students are asked to fill out a questionnaire on responses to learning tools.

\section{B. Field Test Design}

The design of the field trial that will be used is 2 times. The first field trial was conducted to see whether the learning tools that had been developed were effective. If in the first trial the learning device was not effective then it was revised after revised the learning device was re-tested in the second trial. In addition to looking at the effectiveness of learning devices, what will be seen is also the improvement of students' critical thinking skills in the first test results and the second trial.

\section{Development of Learning Devices}

Development of learning tools includes Learning Implementation Plans, Teacher Books, Student Books, Student Worksheets and Students' critical thinking skills tests. The development of this learning tool uses the Dick and Carrey development model which consists of 10 stages [3], namely the identification of instructional objectives, conducting instructional analysis, identifying the characteristics of students, formulating learning activity objectives, developing assessment instruments, developing instructional strategies, developing and selecting learning materials, designing and carry out formative evaluation, revise teaching, develop and carry out summative evaluation.

\section{Development of Research Instruments}

This instrument validity instrument is used to obtain data regarding the opinions of experts (validators) on the learning tools that have been compiled, so that it becomes a reference or guideline in revising the learning device. Learning devices are said to be valid if they meet the level of validity

$$
3 \leq V a<4
$$

\section{E. Instrument for practicality of learning devices}

Practical instruments of learning devices consist of observation sheets and questionnaires. Observation sheets are used to observe the feasibility of learning devices, while questionnaires are used to determine the responses of teachers and students to learning devices whether they are easy and practical to use. Learning devices are said to be practical if: (1) the average minimum implementation is in the category implemented, (2) the average response of the teacher is in the good category, and (3) the average student response is minimal in the good category

\section{F. Instrument for the effectiveness of learning devices}

In analyzing the effectiveness of the device there are three things that are done in this study, namely: (a) analysis of student learning completeness. Trianto (2010) said that the completeness of individual student learning can be obtained by using the following formula:, with $\mathrm{Kb}$ is the completeness of learning, $\mathrm{T}$ is the total score obtained by students, and $\mathrm{Tt}$ is the total score. While the percentage of classical completeness (PKK) is obtained by calculating the percentage of the number of students who complete individually. A class is said to have finished learning if the PKK is $\geq 85 \%$. The percentage can be calculated by the formula; , with the PKK is the percentage of classical completeness, is the number of students who complete learning, and is the number of all students; (b) analysis of the ability of teachers to manage learning. The ability of the teacher is analyzed based on the observation sheet instrument. This instrument is used to obtain data about the teacher's ability to implement learning activities using learning tools through the Problem Based Learning model. Observations are made during learning (from the beginning of learning to the end of the lesson) and observations are made by 2 observers. The ability of teachers to manage learning is said to be effective if the average ability of teachers for all meetings to achieve minimum criteria is quite good $(2.50 \leq$ TKG <3.49); and (c) analysis of student activities can be identified using the observation sheet. This instrument is used to obtain data about student activities during learning using learning tools made through the Problem Based Learning model.

\section{G. Increased Analysis of Critical Thinking}

Data obtained from the results of posttest students 'critical thinking skills in trials I and II were analyzed to determine the improvement of students' critical thinking skills. Ability enhancement can be known by comparing the average scores obtained by students and the average for each indicator of mathematical problem solving ability from the posttest results conducted in the I and II trials.

\section{RESULT}

\section{A. Validation of Learning Devices}

The validators concluded that the Learning Implementation Plans, Student Books, Student Worksheets, and Learning Outcomes Tests could be used with minor revisions to the writing errors / spelling of the question script, and this revision was corrected according to the validator script. The results of the validation of all developed learning tools are presented in table 1 .

\section{B. Practicality of Learning Devices}

Readability test produces data on the quality of learning devices in the form of practicality of learning devices as presented in Table 2. In the table it can be seen that (1) the average minimum implementation is in the well-implemented 
category $(3 \leq \mathrm{Rs}<3,5)$ so that learning tools are developed can be said to be practical.

TABLE 1. Hasil Validasi Perangkat Pembelajaran

\begin{tabular}{|c|c|c|}
\hline Objek yang dinilai & $\begin{array}{l}\text { Rata-rata } \\
\text { validitas }\end{array}$ & $\begin{array}{l}\text { Tingkat } \\
\text { Validasi }\end{array}$ \\
\hline $\begin{array}{l}\text { Rencana Pelaksanaan } \\
\text { Pembelajaran (RPP) }\end{array}$ & & $\begin{array}{l}\text { Sangat } \\
\text { valid }\end{array}$ \\
\hline $\begin{array}{c}\text { Lembar Kerja Siswa } \\
\text { Buku Siswa }\end{array}$ & 4,23 & $\begin{array}{l}\text { Sangat } \\
\text { valid }\end{array}$ \\
\hline $\begin{array}{c}\text { Tes Kemampuan Pemeca- } \\
\text { han Masalah }\end{array}$ & $\begin{array}{l}4,11 \\
3,96\end{array}$ & $\begin{array}{l}\text { Valid } \\
\text { Sangat }\end{array}$ \\
\hline Lembar Keterlaksanaan & 3,84 & valid \\
\hline Perangkat Pembelajaran & 4,13 & Sangat \\
\hline $\begin{array}{c}\text { Lembar Angket Respon } \\
\text { Guru }\end{array}$ & 4,18 & valid \\
\hline Lembar Angket Respon & $\begin{array}{l}3,92 \\
4,17\end{array}$ & $\begin{array}{l}\text { Sangat } \\
\text { valid }\end{array}$ \\
\hline Siswa & 3,99 & Valid \\
\hline $\begin{array}{l}\text { Lembar Aktivitas Siswa } \\
\text { Lembar Kemampuan }\end{array}$ & & Sangat \\
\hline $\begin{array}{c}\text { Guru Mengelola Pembe- } \\
\text { lajaran }\end{array}$ & & Valid \\
\hline
\end{tabular}

TABLE 2. Kepraktisan Perangkat Pembelajaran

\begin{tabular}{lcc}
\hline \multicolumn{1}{c}{ Aspek Kepraktisan } & Rataan & Kategori \\
& Skor & \\
\hline Keterlaksanaan Pera- & 3,92 & Terlaksana \\
$\begin{array}{l}\text { ngkat Pembelajaran } \\
\text { Respon siswa ter- } \\
\text { hadap perangkat } \\
\text { pembelajaran } \\
\begin{array}{l}\text { Respon guru ter- } \\
\text { hadap perangkat } \\
\text { pembelajaran }\end{array}\end{array}$ & 3,31 & Baik \\
\hline
\end{tabular}

\section{Effectiveness of Learning Devices}

The effectiveness of device development products in the application of problem-based learning models in the subject matter of linear programe, can be seen from 3 indicators, namely: 1) students are said to have solved mathematical problems if there are $85 \%$ of students who take the test have minimal mathematical critical thingking skills ( $\geq 70) ; 2$ ) student activities during learning activities meet the criteria for the ideal time tolerance set, 3) the ability of teachers to manage minimal learning is in a pretty good category $(2.50 \leq$ TKG <3.49). Device development products are said to be effective if they meet the three indicators above. The following is described the results of the research on the effectiveness of developing learning tools, which consist of: (a) The ability of teachers to manage learning. The ability of the teacher to manage learning is said to be effective if it is in a good category. In the first field trial, the teacher's ability to manage learning was still in a pretty good category (2.50 3.49 ), so a revision and a second field trial were needed. In the second field trial, the teacher's ability to manage learning was in a fairly good category $(3.50-4.49)$. To see the effectiveness of the teacher's ability to manage learning, researchers conducted observations during the research process; (b) Student Activities. Student activity is measured by observing several students who have represented high, medium and low student groups. Observing student activities is carried out during the research process. In the first and second field trials student activities are in the minimum category of student activity effectiveness; and (c) Student Response. Student responses are measured using student questionnaire sheets. Student responses are related to their interest in the learning tools that have been developed and how teachers manage learning. Giving student response sheets is done at the end of the learning process at each meeting. In the second field trial, the students' response was at $81.78 \%$ which showed a positive response.

\section{Critical Thinking Ability Analysis}

After analyzing the effectiveness of learning devices, the last step taken in this study is to analyze students' critical thinking comprehension.

\section{E. Completeness of Students' Critical Thinking Ability}

In the first field trial the completion of students' critical thinking skills test was still below $85 \%$. Based on the criteria of student learning completeness, the students' ability to think critically in the first trial can be seen from table 3 .

TABLE 3. Hasil Uji Coba Lapangan Pertama

\begin{tabular}{ccc}
\hline Kategori & Jumlah Siswa & Persentase (\%) \\
\hline Tuntas & 28 orang & $73,68 \%$ \\
Tidak Tuntas & 10 orang & $26,32 \%$ \\
Jumlah & 38 orang & $100 \%$ \\
\hline
\end{tabular}

While the second field trial, completeness has reached the classical completeness of $87 \%$. Based on the criteria of student learning completeness, the students' ability to think critically in the second field trial can be seen from Table 4 . 
TABLE 4. Hasil Uji Coba Lapangan Kedua

\begin{tabular}{ccc}
\hline Kategori & Jumlah Siswa & Persentase (\%) \\
\hline Tuntas & 33 orang & $86,84 \%$ \\
Tidak Tuntas & 5 orang & $13,16 \%$ \\
Jumlah & 38 orang & $100 \%$ \\
\hline
\end{tabular}

Overview of the results of the students' critical thinking skills test in the first field trial and the second field trial is shown in table 5

TABLE 5. Hasil Tes Kemampuan Pemecahan Per-tama (kiri) dan Kedua (kanan)

\begin{tabular}{|c|c|c|c|}
\hline Keterangan & $\begin{array}{c}\text { Nilai } \\
\text { Tes }\end{array}$ & Keterangan & $\begin{array}{c}\text { Nilai } \\
\text { Tes }\end{array}$ \\
\hline Nilai Tertinggi & 3,44 & Nilai Tertinggi & 3,60 \\
\hline Nilai Terendah & 2,08 & Nilai Terendah & 2,32 \\
\hline Rata-rata & 2,68 & Rata-rata & 2,94 \\
\hline
\end{tabular}

Increased critical thinking skills increased by 1.47 .

\section{CONCLUSIONS}

Conclusions in this study are: (1) The ability of teachers to manage learning by using learning tools using learning tools oriented to problem based learning has been effective and achieved good categories; (2) The activities of students during the learning process using learning tools oriented to problem based learning are already on the criteria for limiting the effectiveness of learning; and (3) the student's response to the components of the learning device has shown a positive response, as seen from the $81.78 \%$ student response; and (4) Learning tools that have been developed and stated to be effective, then analyzed how to improve students' mathematical problem solving abilities that have been implemented in the first and second field trials. Classically $86.84 \%$. While the improvement of students' mathematical critical thingking ability in the first field trial was 2.67 which increased to 2.94 in the second field trial. Mathematical critical thingking ability of students has a significant increase of $0.27(6.75 \%)$.

\section{References}

[1] Depdiknas, "The guidelines choose to arrange teaching materials and subject texts", Bp Mitra usaha Indonesia

[2] Simbolon.M., Mulyono.,Syahputra.E., and Surya.E., (2017) ., The Efforts to Improving the Mathematical Critical Thinking student's Ability through problem solving Learning Strategy by using Macro Media Flash. American Journal of Educational Research, Vol.5, N0.7,2017

[3] Dick, W and Carrey, L. (1985). The Systematic Design Instruction. Secon edition. Glenview. Illinois: Scott., Foreman and Company

[4] Trianto; (2007)" Integrated Learning models in theory and practice".Jakarta: Prestasi Pustaka 